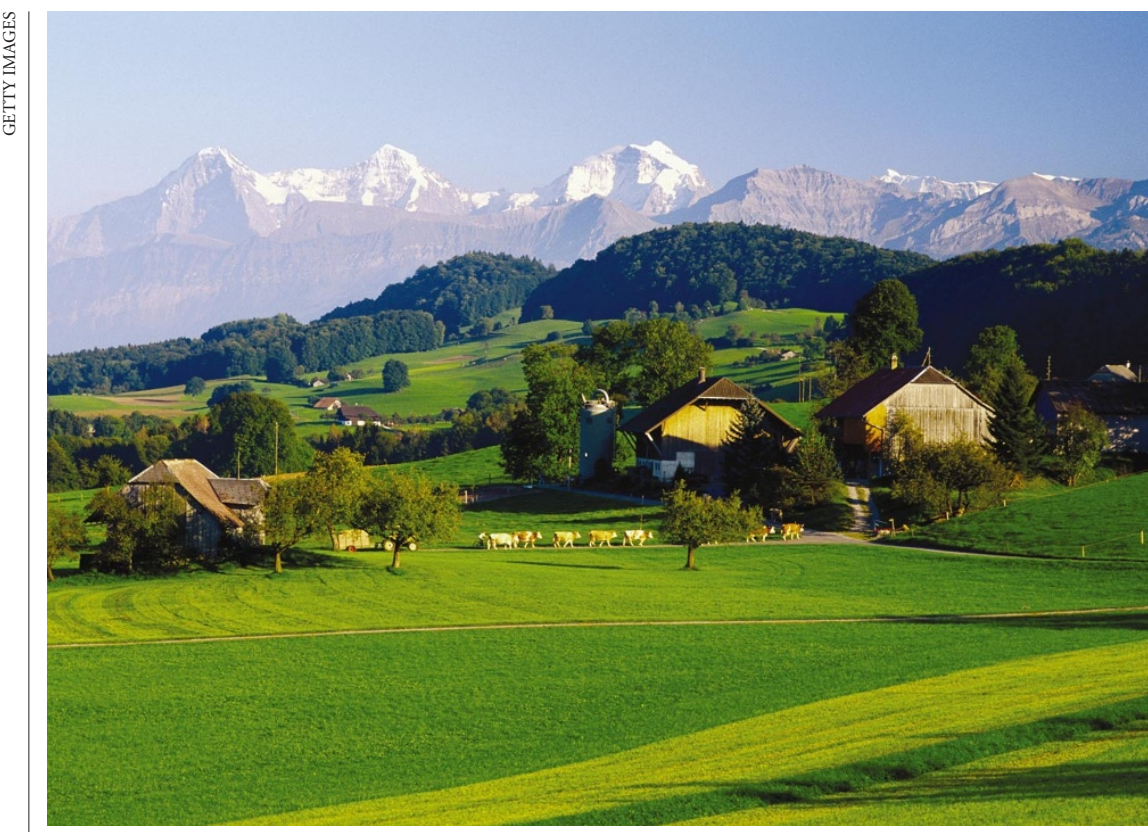

Biotechnologists hoping to run crop trials in Switzerland will face a veritable mountain of regulation.

\section{Swiss law imposes iron rule on biotechnology field trials}

\section{Quirin Schiermeier, Munich}

The Swiss parliament last week passed a law setting some of the world's toughest restrictions on the conduct of trials of genetically modified crops.

The bill, which was passed on 2 October, allows trials of transgenic crops to be carried out, but only if they can jump through a set of strict regulatory hoops. It was nonetheless greeted as a qualified success by Switzerland's large agricultural biotechnology industry, which hopes that the law will end a de facto moratorium on such trials. But the legislation must still be debated in the Swiss second chamber and could yet be challenged in a referendum.

The new law, known as Gen-Lex, was conceived by the Swiss government to draw the sting from environmentalists' attempts in a 1998 referendum to outlaw all such trials. The referendum, which failed by a narrow majority, would have banned field trials of genetically modified crops, as well as the creation of transgenic animals (see Nature $393,507 ; 1998)$.

If confirmed, the new law will require applicants to prove that their research cannot be carried out under laboratory conditions and that, if released, the crops are unlikely to cross-pollinate non-transgenic plants or otherwise contaminate the environment. All trials must also include a research component on the biosafety of the experiments.

Almost 200 researchers had signed a plea asking for a more research-friendly law. But despite the tight restrictions, they will be relieved to at last have a realistic prospect of carrying out field trials. The lack of trials had threatened to cut off Swiss researchers from new developments in molecular plant research and botany, they say.

"The bill sets very high hurdles for the approval of transgenic plant releases, but it could have been worse," says Daniel Schümperli of the Institute of Cell Biology at the University of Bern, and chair of the Swiss Academy of Sciences' forum on genetic engineering. A step-by-step approach, he says, similar to the phases of clinical trials, should allow plant scientists to meet the requirements and minimize the environmental risks associated with field trials of transgenic crops.

The biotechnology industry also welcomed the bill's passage. "The small Swiss market is not our main concern," explains Arthur Einsele, a spokesman for Syngenta, one of the world's largest agricultural biotechnology companies, whose headquarters are in Basel. "But a moratorium would have been a very bad signal for the European Union. We have an interest in our headquarters being based in a country with a positive research climate."

But Switzerland remains deeply divided over the issue of agricultural biotechnology. The law could be modified by the second chamber of parliament, and environmental groups have said they will attempt to call a referendum if any more concessions are made to facilitate field trials.

\section{Winning universities set out to fulfil Japan's plans for excellence}

\section{David Cyranoski, Tokyo}

Japan's education ministry has named the first 113 centres of excellence to be set up at the nation's universities.

The programme, which aims to make Japanese research more competitive, saw 464 groups from 163 public and private universities compete for the awards.

"Until now, Japan has favoured stability in funding, but now it is leaning towards competition," says Yuichiro Anzai, president of Keio University in Tokyo and a co-chairman of the programme.

The winning centres will each receive grants worth between $¥ 100$ million and $¥ 500$ million (US\$800,000 to $\$ 4$ million) per year for a renewable five-year term although an unfavourable review after just two years can close any of the centres.

Teams of about 20 professors competed for the grants in five fields - life sciences, chemistry and materials, information technology and electronics, humanities, and a broad category of interdisciplinary topics, including environmental science and energy research.

The chosen centres span 50 universities, with 49 of the centres based at the 7 former imperial universities. The University of Tokyo and Kyoto University lead the pack with 11 centres apiece.

But critics complain that the selection standards were not made clear — and that the government has not provided any feedback on how projects were chosen.

"Most people do not believe this programme has been considered carefully," claims one referee for the programme, who declined to be named. Some researchers also say that the money could have been better spent on fewer, larger projects.

But most scientists are optimistic that the programme will boost high-quality, multidisciplinary research. "More competition will have a great effect on Japanese universities," says Tadamitsu Kishimoto, president of Osaka University.

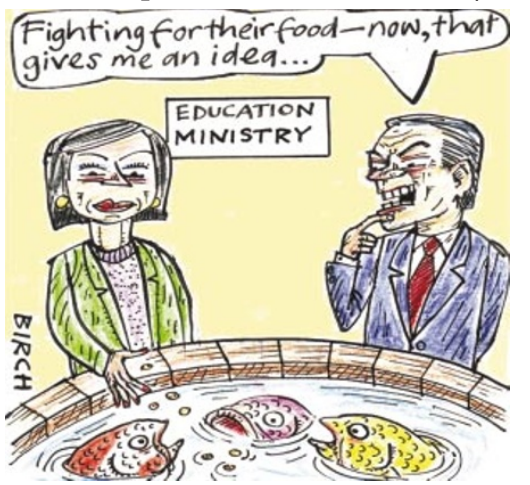

